\title{
Mechanistic action of AgNps (silver nanoparticles) in apoptosis of MCF-7- cell lines
}

\author{
Jasmine Mathew* and Vandana Rathod \\ Department of Microbiology Gulbarga university, Kalaburgi, Karnataka 585106 \\ *Email: jasminemathew292@gmail.com
}

Nanomedicine is an emerging field that could potentially make a major impact on human health. Amongst various nanoparticles, silver nanoparticles (AgNps) have an eyecatching role owing to their innumerable significant properties. Cytotoxicity studies of AgNps from the fungus Aspergillus pseudodeflectus on MCF-7 cell lines showed a $\mathrm{CTC}_{50}$ value of $200 \mu \mathrm{g} / \mathrm{ml}$ (Table -1$)$ proving that AgNps have good cytotoxic effect on MCF-7 cell lines.

Table 1: Cytotoxic properties of AgNps against $\mathrm{MCF}-7$ cell line

\begin{tabular}{|l|l|l|}
\hline $\begin{array}{l}\text { Conc. of } \\
\text { AgNps } \\
((\mu \mathrm{g} / \mathrm{ml})\end{array}$ & $\begin{array}{l}\% \\
\text { Cytotoxicity }\end{array}$ & $\begin{array}{l}\mathrm{CTC}_{50} \\
(\mu \mathrm{g} / \mathrm{ml})\end{array}$ \\
\hline 400 & $64.47 \pm 0.9$ & \\
200 & $49.01 \pm 0.9$ & \\
100 & $36.07 \pm 2.0$ & $200 \mu \mathrm{g} / \mathrm{ml}$ \\
50 & $23.57 \pm 2.6$ & \\
25 & $3.84 \pm 1.2$ & \\
\hline
\end{tabular}

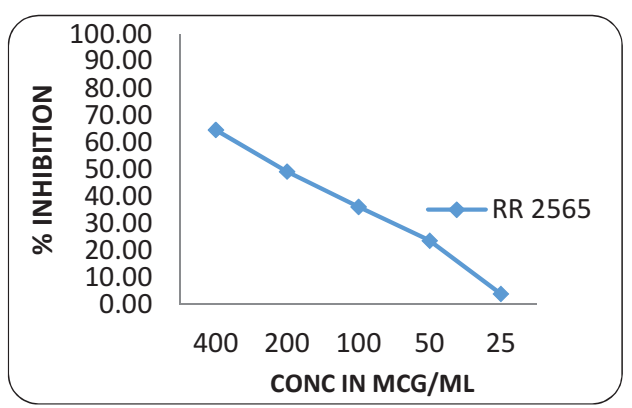

Graph 1: Cytotoxic effect of AgNps on MCF-7 Cell line

Through literature the mechanistic action of AgNps against cancer cells revealed, the proteins having functional groups of either amino or carboxyl groups conjugated with the surface of AgNps evidenced through FTIR results (Graph-2), plays a pivotal role in uptake of AgNps by the cancer cells via endocytosis (Figure 1).

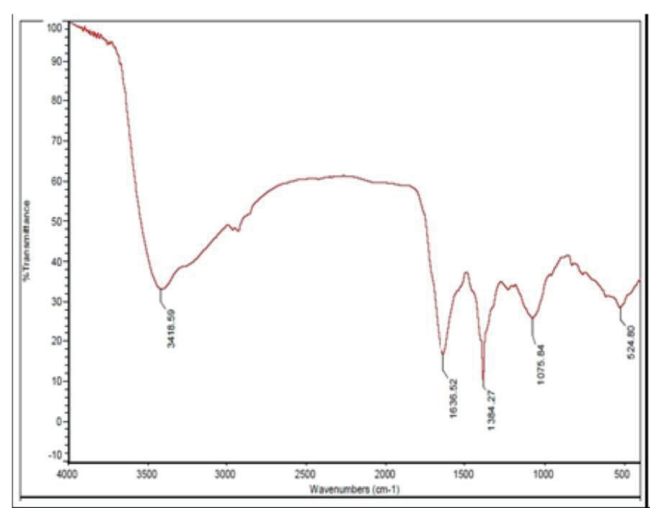

Graph 2: FTIR spectrum of AgNps

$\mathrm{AgNps}$ enter into the cytosol with in endosome which later fuse with the lysosome to give rise to endolysosome which is characterized by acidic environment.Inside the endolysosomes the AgNps are broken down forming amino acids and $\mathrm{Ag}^{+}$ions. These ions produce ROS at mitochondrial levels generating a disfunction and activation of caspases resulting in apoptosis. As there is continuous search for novel and affordable anticancer agents, AgNps in the form of anticancer drugs in combination with other adjuvants or AgNps alone will be a boon to the cancer therapy.

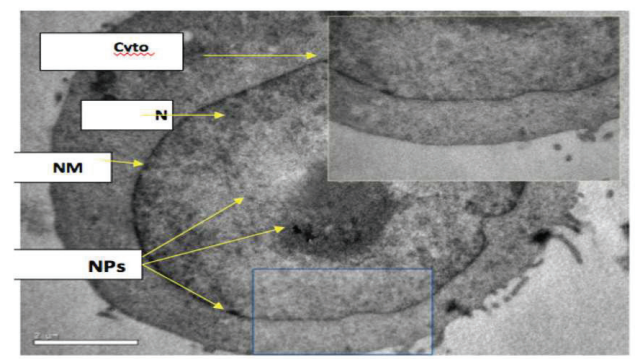

Figure 1: AGNPS inside the cytosol 